\title{
ジルコニア結晶の強弾性ドメインスイッチングに及ぼす応力, 温度の影響
}

\author{
木口賢紀・漆原 亘 $^{*} \cdot$ 佐伯 淳 ·篠㟝和夫 · 水谷惟恭 \\ 東京工業大学工学部無機材料工学科, 152 東京都目黒区大岡山 2-12-1
} *神戸製鋼所 (株) 材料研究所, 651-22 兵庫県神戸市西区高塚台 1-5-5

\section{Effect of Stress and Temperature on Ferroelastic Domain Switching of Partially Stabilized Zirconia Pseudo-Single Crystals}

Takanori KIGUCHI, Wataru URUSHIHARA*, Atsushi SAIKI, Kazuo SHINOZAKI and Nobuyasu MIZUTANI

Department of Inorganic Materials, Faculty of Engineering, Tokyo Institute of Technology, 2-12-1, O-okayama, Meguro-ku, Tokyo 152 *Materials Research Laboratory, Kobe Steel, Ltd., 5-5, Takatukadai 1-chome, Nishi-ku, Kobe-shi, Hyogo 651-22

\begin{abstract}
The effect of temperature and applied stress on the ferroelastic behavior of partially stabilized zirconia pseudo-single crystals doped with $3 \mathrm{~mol} \%$ yttria was studied using a uniaxial compression method at high temperature. X-ray diffraction patterns showed that the ferroelastic domains were rearranged to orthogonal two directions. The amount of domain switching increased with increasing applied stress but remained with loading time. The critical stress required to induce the ferroelastic domain switching decreased with increasing temperature; $200 \mathrm{MPa}$ at $700^{\circ} \mathrm{C}, 160 \mathrm{MPa}$ at $800^{\circ} \mathrm{C}, 125 \mathrm{MPa}$ at $1000^{\circ} \mathrm{C}$ and $100 \mathrm{MPa}$ at $1200^{\circ} \mathrm{C}$. The activation energy of domain switching was calculated to be about $16 \mathrm{~kJ} / \mathrm{mol}$ using critical stress vs. temperature plot. The model for explaining a domain switching mechanism was proposed on the basis of the displacement of ions.
\end{abstract}

[Received November 1, 1995; Accepted March 15, 1996]

Key-words : Ferroelastic domain switching, Partially stabilized zirconia, Activation energy, Critical stress, Oxygen ion

\section{1. 緒 言}

部分安定化ジルコニア（partially stabilized zirconia; PSZ)は, 高勒性・高強度構造材料として注目されている. PSZの高強度や高勒性化の機構には主に応力誘起変態強 化, マイクロクラック強化, 粒子架橋強化, 亀裂迁回偏向 強化, 表面変態強化等が考えられている11. しかしながら 正方晶から単斜晶への相転移が起こらないで，しかも上述 のいずれの機構にも該当しないのに高勒性を示す場合が報 告されている．例えば，PSZにおいて $700^{\circ} \mathrm{C}$ 以上では正方 晶が他形よりも安定に存在できるので正方晶から単斜晶へ の応力誘起変態は起こりにくくなる. Michelらは，この 条件下では応力印加後も単斜晶の存在が認められないが, この PSZ は安定化ジルコニアに比べて同じ温度での破壊 勒性值が約 3 倍もの高い值を示したことを報告している2). 更にジルコニアは立方晶（高対称相）が点群 $m 3 m$ に, 正方晶（低対称相）は点群 $4 / \mathrm{mm} m$ に属しており, 相津 の記号では $m 3 \mathrm{mF} 4 / \mathrm{mmm}$ という種（species）に属する 強弾性体であることを最初に認識した2),3)。これらの結果 を解析して，1986年に Virkar らが「正方晶ジルコニアに 抒いて, 応力下で正方晶から単斜晶へ相転移せずに，ドメ イン構造を持った正方晶格子の $a$ 軸と $c$ 軸が入れ替わって 再配向する（強弾性ドメインスイッチング）」という現象 を提唱しだ)。強弾性という概念は，1960年代後半に相 津 ${ }^{3), 55,6)}$ が強磁性及び強誘電性との類似現象として提案し たものであり,「無応力下で複数種の配向状態（ドメイン） を持ち,これらの状態間を適当な応力により遷移しうると
き強弾性と呼ぶ.ただし，これらの配向状態のどの二つも 結晶構造に関して同一か鏡像的であり, 無応力下での歪み テンソルに関して相異なるものとする」と定義されてい る4) 9) . 各配向状態（ドメイン）は，無応力下において 等価なエネルギー状態にあるが，応力が印加されることに より一方のドメインがエネルギ一的に不安定になり, この ドメインがドメイン間に存在する活性化状態を超えられた ときドメインスイッチングが進行する. 強弾性体の応力歪み曲線はヒステリシスを示すことから，この強弾性ドメ インスイッチングが破壊エネルギーを吸収する重要な勒性 強化機構であると考えられている4).

$\mathrm{ZrO}_{2}$ のドメインスイッチングについてのいくつかの研 究がなされてきたが，そのほとんどがドメインスイッチン グ現象の確認だけに終わっている10)〜16)。したがってドメ インスイッチングと応力や温度などとの関係を明らかに し，ドメインスイッチングの機構を解明することは非常に 重要である。

本研究に抢いては, 粒界の影響を除くためフローティン グゾーン $(\mathrm{FZ})$ 法で育成した $\mathrm{Y}_{2} \mathrm{O}_{3}$ 部分安定化 $\mathrm{ZrO}_{2}$ 結晶 を用いて，温度及び印加応力とスイッチング量との関係を 定量的に測定し，ドメインスイッチングに及ぼす影響を調 ベることを目的とした。

\section{2. 実験方法}

\section{1 試料結晶の作製}

本研究で用いた $3 \mathrm{~mol} \%$ イットリア部分安定化ジルコニ 
ア（3Y-PSZ）の結晶は, アークイメージFZ 法による既 報の方法で作製した17)。育成した結晶棒の径は約 3.2 $\mathrm{mm} \phi$ であった。結晶方位は背面反射ラウエ法によって決 定した，育成した結晶棒を約 $5 \mathrm{~mm}$ ずつ切り出し，切断 面で率る(100) (010) (001)面をそれぞれ \#1500なでダイ ヤモンドディスクで鏡面研磨したＦZ 法で育成した YPSZ 結晶は育成方向に正方晶の $c$ 軸が配向しやすい傾向 がある，そこで育成方向に垂直な面を(001)面，他の 2 面 をそれぞれ(010)(100)面々定義した。切断面の法線方向 は結晶方位から最大で約 6 の傾斜が見られた。これは結晶 育成や研磿の際に生じた傾きであると考えられ，この程度 の誤差は実験上制御できなかった。

\section{2 高温一軸圧縮装置}

本実験では, 応力印加のためにオートグラフ（島津製作 所製，DSS-500型）の試料加圧部を図 1 のように改良し て高温測定が行えるようにした。 $1000^{\circ} \mathrm{C}$ まの加熱には 電気炉のみを用い， $1000^{\circ} \mathrm{C}$ 以上の加熱にはこれを補助炉 として使用し, $\mathrm{ZrO}_{2}$ 結晶自体に直流を流して自己発熱に よる方法を用いた。目的の温度に達したところで $5 \times 10^{-3}$ $\mathrm{mm} / \mathrm{min}$ の荷重速度で応力を印加した. 1 個の測定点につ いて 3 回ないし 4 回の測定を行った. 試料のセットは, 押し棒ーアルミナー電極 (ステンレス) -白金板-試料電極 (Y-PSZ 結晶, $1.5 \mathrm{~mm}$ 厚, 試料大) -試料-試料電極一白 金板一電極ーアルミナー試料台の順で組名合わせた。炉の中 央に穴を開け，赤外線放射温度計で試料温度を測定した。 $\mathrm{ZrO}_{2}$ 結晶の放射率は佐伯の結果から0.43とした ${ }^{18)}$.

\section{3 極点図形による $c$ 軸配向度の測定}

極点図形測定装置（Philips 社製 PW-1078/50）を用 いてて ${ }^{19)}$ ，試料の方向に対する特定の配向をステレオ投影 し，極の配向とともに極の密度の測定を行った．測定は反 射法により試料の $(100)$ 極の方向 $(\psi, \phi)$ を知り，その方 向での (002) (200) ピーク強度測定した $(\theta-2 \theta$ 測定). 測定した (002) (200)の回折ピークをプログラム（profile

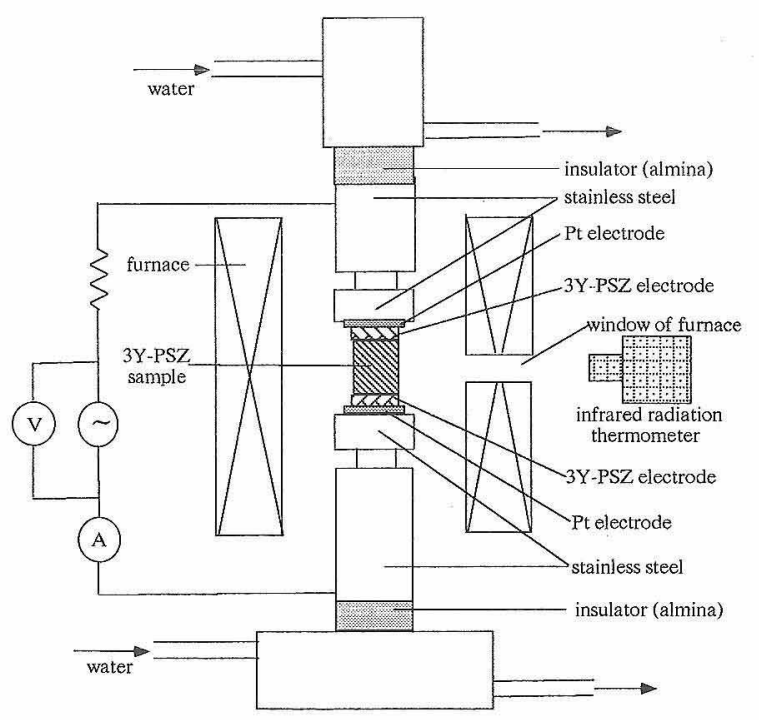

Fig. 1. The apparatus for measurement of stress-strain curve at high temperature. fit Philips PW-1078/50)により分離し, ピーク強度を比 で表した。(002) ピーク比率として, $c$ 軸配向度 $F=$ $I(002) /[I(002)+I(200)](F$ 值: $F$-value $)$ を用いた。本 論文ではドメインスイッチングの発生量を $c$ 軸配向度の変 化量で表すことにする．配向度の測定は各試料について応 力印加の前と後で行った.

\section{3. 結果と考察}

\section{1 ドメインスイッチングの確認}

図 2 に $800^{\circ} \mathrm{C}$ で (001) 面に応力を印加したときの，(100) (010) (001)の各面について測定した(002) (200)ピークの $\mathrm{X}$ 線回折図形を示す。初期状態は結晶棒ごとにほぼ等し かった。 またこの結果から単斜晶の (002) ピークが観察さ れた。そこで単斜晶の極方向を極点回折によって調べ，そ の方向での $\theta-2 \theta$ 測定を行った結果, 単斜晶ピークは正方 晶のバックグラウンドに隠れるほど小さいが存在すること が分かった（001)面では (002)ピークの減少と(200)ピー クの増加, (010) と(100) 面では (002) ピークの增加と (200) ピークの減少が見られたことから, 応力方向に対し て $c$ 軸から $a$ 軸への変換すなわちドメインスイッチングが 起こっていることが確認された。応力が大きいほどこの変 化の割合が大きく、ドメインスイッチング量は応力に依存

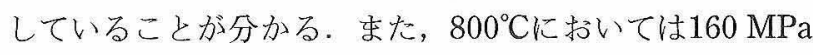
未満の応力ではピーク強度に変化が見られず，試料は弾性 的な挙動を示しドメインスイッチングは起こっていないと

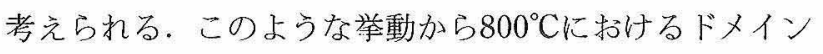
スイッチングの開始応力（以下臨界応力と呼ぶ） 160 $\mathrm{MPa}$ とした。圧縮後の試料において単斜晶の $(002)$ ピー クの増加は見られなかった。このことから一軸圧縮したと

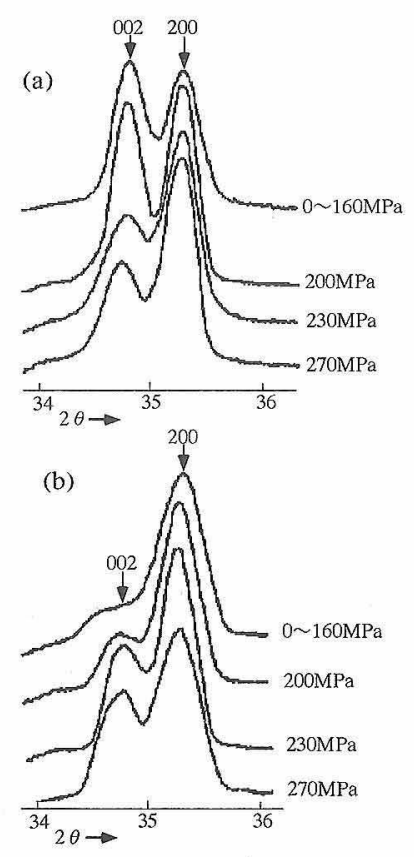

Fig. 2. (002) (200) diffraction pattern change by compressive stress $\left(800^{\circ} \mathrm{C}, 200 \mathrm{MPa}\right)$

(a) (001) face, (b) (100) and (010) faces. 
き, 正方晶から単斜晶への相転移が起こらないことが確認 できた。

\section{2 ドメインスイッチングの特徴}

\subsection{1 応力印加時間}

PZT に打いて試料全体にわたるドメインスイッチング に要する時間が数秒である20) という報告があることから， ドメインスイッチングは臨界值を超す応力を印加すると瞬 間的に起こると考えられる. 一定の歪み速度の下での応力 印加にはこれよりも長い時間を要するので時間依存性は観 測されないと考えられるが, その後も応力を印加し続けた 場合, 緩和的に軸変換量が変化するかどうかを調べるた め, 応力印加時間を $2 \mathrm{~min}, 60 \mathrm{~min}, 240 \mathrm{~min}$ として(001) 面に $800^{\circ} \mathrm{C}$ で $200 \mathrm{MPa}$ の応力を印加した。結果を図 3 に示 す. 軸変換量は応力印加時間に依存せずに一定值を示し た.この結果から, 以下の試験では応力保持時間を 2 min で統一してもよいと判断した.

\subsection{2 印加応力によるスイッチング量の変化}

温度を変化させて, 各温度で軸変換の応力依存性につい

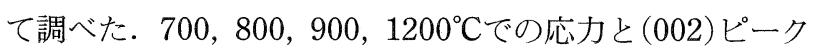
比率の関係をそれぞれ図 4 (a)〜 (d) に示した. な抢加熱

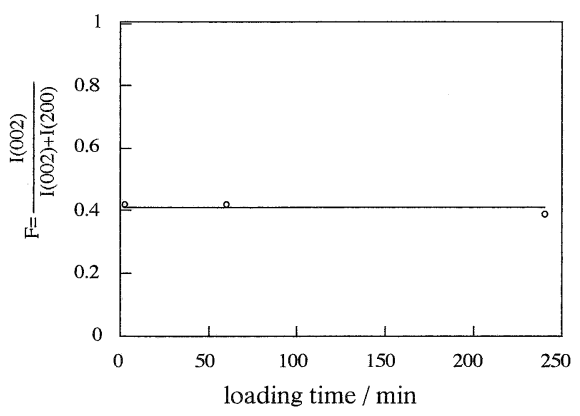

Fig. 3. Change of $F$-value with loading time.
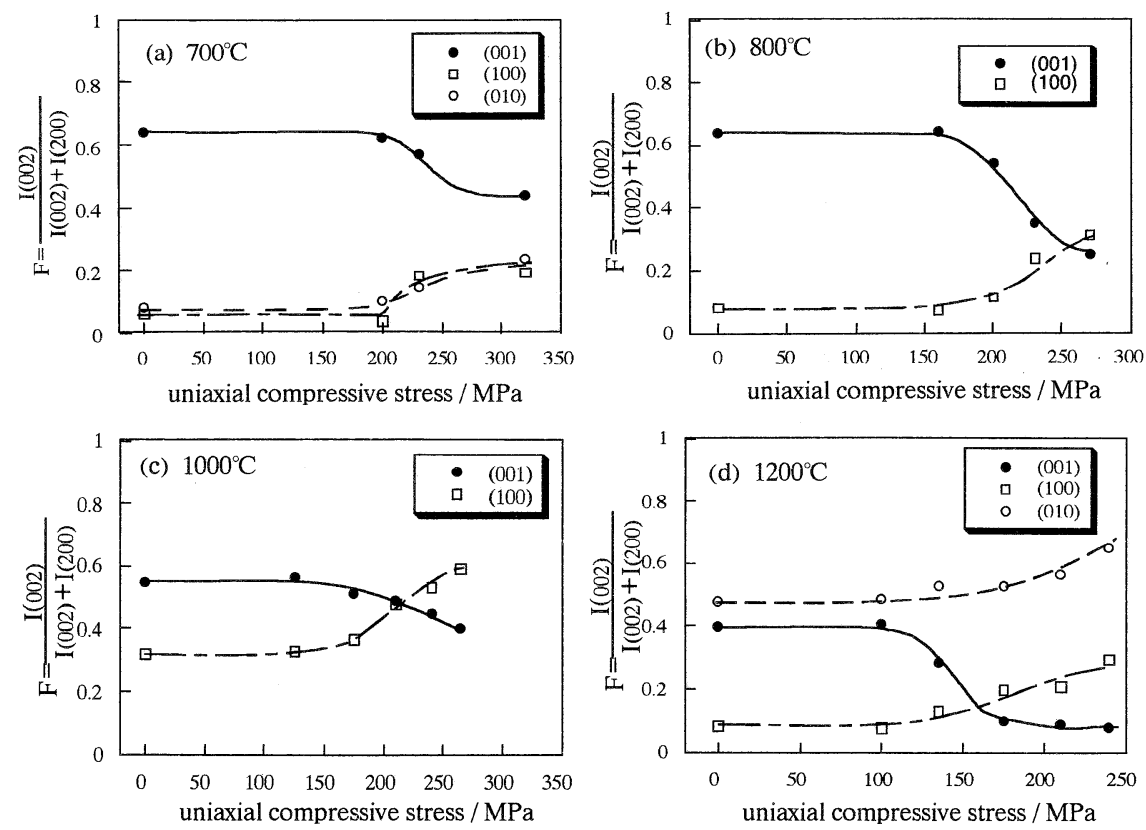

Fig. 4. Change of $F$-value with applied stress and temperature. (a) $700^{\circ} \mathrm{C}$, (b) $800^{\circ} \mathrm{C}$, (c) $1000^{\circ} \mathrm{C}$ and (d) $1200^{\circ} \mathrm{C}$. 
ングして単一のドメインに成長するよりも，2 方向にス イッチングして新たなドメイン構造を形成する方が，隣接 するドメイン同士が互いに歪みを打ち消し合い，新たなド メイン構造形成に伴う歪みエネルギ一増加を最小限に押さ えることができる.したがってスイッチングの際により多 くの歪みエネルギーを解放することができるので, 応力印 加方向に垂直な 2 方向に $c$ 軸を持つドメイン構造が形成さ れると考えられる.

\section{3 臨界応力の温度変化}

図 4 からスイッチングの臨界応力は, $700^{\circ} \mathrm{C} て ゙ 200$ $\mathrm{MPa}, 800^{\circ} \mathrm{C}$ で $160 \mathrm{MPa}, 1000^{\circ} \mathrm{C}$ で $125 \mathrm{MPa}, 1200^{\circ} \mathrm{C}$ で 100 $\mathrm{MPa}$ となり, 温度が高いほどスイッチングの臨界応力が 小さくなっていることが分かる。

一般に温度の上昇に伴ってイオンの熱振動が激しくな り，各イオン間の結合距離が増加する. 結合距離が長くな るほどイオンの結合力は弱くなるから，高温になるほどイ オンの変位が容易になる ${ }^{22)}$. 正方晶 $\mathrm{ZrO}_{2}$ の格子定数は $c$ 軸の方が $a$ 軸よりも長く，したがって $c$ 軸方向のイオン間 結合距離が $a$ 軸方向よりも弱い。 また，熱膨張が異方性 を示し， $c$ 軸方向の方が $a$ 軸方向よりも大きな熱膨張率に なっており，例えば3Y-TZP の熱膨張係数は $c$ 軸方向の值 が $a$ 軸方向の約1.2倍の大きさである23) 25). したがって, 高温になるにつれて特に $c$ 軸方向の結合力が $a$ 軸方向と比 較して弱丈るため，より低い $c$ 軸方向への圧縮応力で $c$ 軸 から $a$ 軸への軸変換つまりドメインスイッチングが起こ るようになったと考えられる.

このようにドメインスイッチングは熱活性化過程である ので, 活性化エネルギーが存在すると考えられる，そこで 次に示す歪及速度と応力の間に成り立つ関係式（(1)式） を用いてドメインスイッチングの見掛けの活性化エネル ギーを求めた ${ }^{26)}$.

$$
\sigma=A \dot{\varepsilon} \exp \left(\frac{\Delta E}{R T}\right)
$$

ただし $\sigma$ は臨界応力(スイッチング開始応力), $A$ は定数, $\dot{\varepsilon}$ は歪久速度 (本実験では一定), $\Delta E$ は歪久速度一定の下 でのドメインスイッチングの見掛けの活性化エネルギー, $T$ は絶対温度, $R$ は気体定数である. 実際は歪久速度は 一定ではなかったが, その変化は最大でも $0.3 \%$ 未満で あったので一定であるとみなした．この式は高温クリープ 変形に対して成り立つ式であるが，クリープと比較すると ドメインスイッチングは原子の移動距離にこそ違いがある が，原子の移動によって起こり，熱によって活性化され， 歪み速度にも依存するという点でいずれの現象も応力が関 係した熱活性化過程であると考え, ドメインスイッチング に対してこの式の適用を試みた.この式の両辺の対数を とった(2)式

$$
\ln \sigma=\frac{\Delta E}{R T}+\ln A \dot{\varepsilon}
$$

は $\ln \sigma$ が $1 / T$ に比例することを示している. そこで図 4 から得られたデータから $\ln \sigma$ 対 $1 / T$ プロットを行うと 図 5 のように両者の関係は直線となり，その傾きから 3

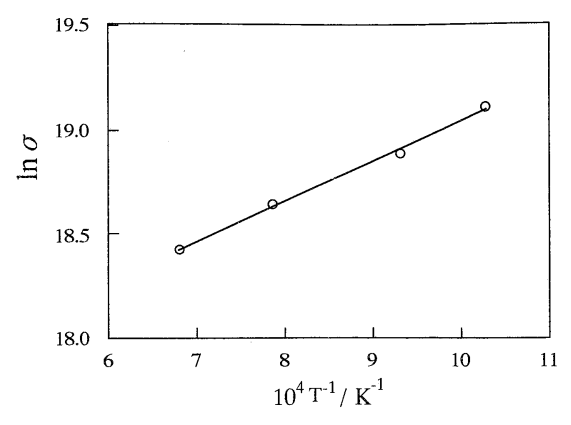

Fig. 5. $\ln \sigma$ vs. $T^{-1}$ plot. $\sigma$ : critical stress.

$\mathrm{mol} \% \mathrm{Y}_{2} \mathrm{O}_{3}-\mathrm{ZrO}_{2}$ のドメインスイッチングの見掛けの活性 化エネルギーは約 $16 \mathrm{~kJ} / \mathrm{mol}$ となった. $\mathrm{ZrO}_{2}$ における酸 素イオンの拡散の活性化エネルギー約 $120 \mathrm{~kJ} / \mathrm{mol}$, ジル コニウムイオンの拡散の活性化エネルギー約 $440 \mathrm{~kJ} /$ $\mathrm{mol}^{27)}$, 圧縮試験による超塑性変形の活性化エネルギ一約 $380 \mathrm{~kJ} / \mathrm{mol}^{26)}$ と比べてドメインスイッチングの活性化エ ネルギーの值は 1 けた小さいものとなっている. 一般に 拡散に抢ける活性化エネルギーはイオン間の結合の切断に 要するエネルギ一, 移動の際に周囲のイオンから受ける反 発に打ち勝つためのエネルギー（以上イオンの移動に要す るエネルギー）と移動先のサイトに空孔を作るためのエネ ルギーの和であると考えられている. 拡散や超塑性変形に おいてはイオンが結合を切断してその結合距離 $(0.1 \mathrm{~nm}$ オーダー）あるいはそれ以上を移動する必要があるのに対 して, ドメインスイッチングではイオンは結合を切断する ことなく結合距離をわずかに伸縮し，単一格子内で格子定 数の $10 \%$ 未満（0.01 nm オーダー）の距離だけ変位すれば よく, 隣接するサイトに空孔を生成させる必要もない。こ のことから，ドメインスイッチングに抢ける活性化エネル ギーは, 主にイオン間の結合距離に微小な伸縮に要するエ ネルギーとイオンの変位の際に周囲のイオンから受ける反 発に打ち勝つためのエネルギーから構成されていると考え られる. 更にこの二つのエネルギ一はそれぞれイオン間の 結合の切断に要するエネルギ一，隣接するイオンサイトへ の移動の際に周囲のイオンから受ける反発に打ち勝つため のエネルギーに比べて十分に小さいと予想され，ドメイン スイッチングの活性化エネルギーの值が拡散や超塑性変形 の活性化エネルギーよりもはるかに小さい值であったこと は妥当であると考えられる.

一般に結晶の強弾性相転移における，自発歪みの発生に 関連したエネルギー変化は $6 \mathrm{~kJ} / \mathrm{mol}$ 程度である21). 3 $\mathrm{mol} \% \mathrm{Y}_{2} \mathrm{O}_{3}-\mathrm{ZrO}_{2}$ の立方晶から正方晶への相転移温度は約 $2000^{\circ} \mathrm{C}$ であり ${ }^{28)}, 1000^{\circ} \mathrm{C}$ 付近までは軸比が単調に増加し て $1.7 \%$ 程度の増加が見られる ${ }^{22)} .1000^{\circ} \mathrm{C}$ から室温にかけ て軸比はわずかに減少するが，最初の状態に比べると 1.5 から1.7\%程度増加している ${ }^{22)}$.この軸比を用いて相津の 定義 ${ }^{29)}$ から自発歪みの大きさを計算すると, $1000^{\circ} \mathrm{C}$ 付近 では1.4\%程度の自発歪みが生じていることになる。この 自発歪みに伴うエネルギーは $6 \sim 7 \mathrm{~kJ} / \mathrm{mol}$ に達する。し たがって正方晶の $c$ 軸方向への圧縮によって立方対称の状 
態へ変形させるには，6～ $7 \mathrm{~kJ} / \mathrm{mol}$ 程度の弾性エネルギー を要する。これが活性化エネルギーになると考えられる

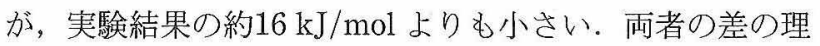
由は現在のところ分からないが，可能性のある原因として ドメインウォール間の相互作用やドメインウォールと格子 欠陷との相互作用が考えられる。ドメインウォール同士は 相互作用して反発し合っているためドメインウォールの移 動を妨げ，このドメインウォール間の相互作用により見掛 けの活性化エネルギーが増加する. 更に結晶中に存在して いる格子欠陷，例えば点欠陷や転位，が周囲に応力場を生 じているため ${ }^{30)}$ ，格子欠陥とドメインウォールとの相互 作用によって見掛けの活性化エネルギーが増加する。した がって本実験から得られたドメインスイッチングの見掛け の活性化工ネルギーは，純粋に格子が正方晶から立方晶八 歪むのに要するエネルギーよりも大きな值になったと考え られるが，それでも拡散などに比べると十分に小さい值で ある。

\section{4 ドメインスイッチング機構}

ドメインスイッチングはドメインウォールの移動による ドメインの消長であることは上述したが，ドメインウォー ルの移動に伴う原子の変位については触れていない.ここ ではこの点について考える。

図 4 から, 印加応力がスイッチングの起こる臨界応力 の大きさに達するまでは格子の変形（イオンの変位）が弾 性的に行われ, 印加応力を除荷すると応力印加前の状態に 回復することが分かる。 またドメインスイッチングには活 性化エネルギーが存在することから, 活性化状態が存在す ると考えられる。これらの結果からドメインスイッチング に抢けるイオンの変位モデルを考え，図 6 に示す。図 6 (a)はスイッチングの立体的な変化を示し，（b)は分かり やすくするために(a)を $x$ 軸方向から $y z$ 平面上に正射影し

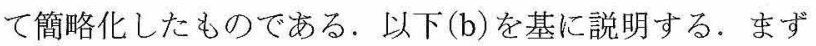
印加応力が臨界応力に満たない間はスイッチング前の配向 状態（配向状態 1) と活性化状熊との間で，正方晶から立 方晶的に格子が弾性的に歪むようにイオンが变位し，理想 的な蛍石構造に近づく，応力を除荷すると各イオンが初め の配向状態の正方晶のサイトに戻る. 印加応力が臨界応力 以上になると，ドメインスイッチングの活性化状態に達す る.この状態ではジルコニウムイオンの周冊の酸素イオン が過密になって扔りエネルギ一的に不安定であるので，初 めとは異なる配向状態へ強弾性的に各イオンが变位して格 子が歪み，エネルギ一的により安定なスイッチング後の配 向状態（配向状態 2) になる。このとき歪みの方向 $(c$ 軸

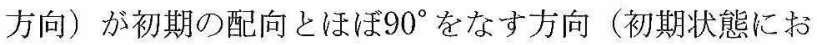
ける $a$ 軸方向）に配向しており，応力を除荷しても再び 活性化状態を超えられないためこの配向状態が維持され る。

一般に強弾性体を初めとするフェロ結晶（ferroic crystal）のうち変位型の相転移を行うものは，ドメインス イッチングの際に相転移に逆らう方向つまりフェロ相 (ferroic phase) から原型相（prototype）と呼ばれるより

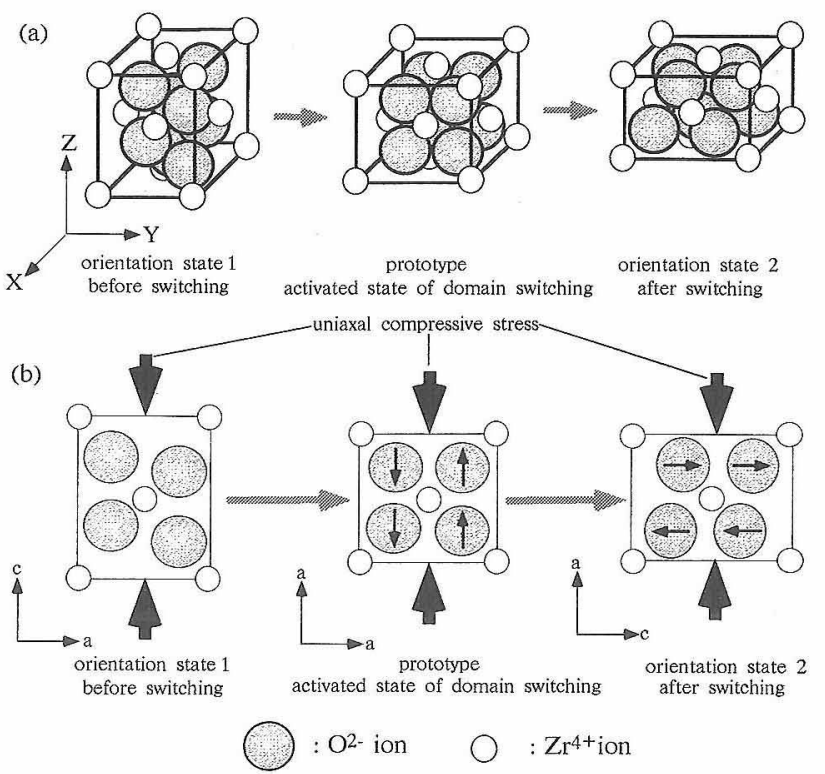

Fig. 6. Schematic diagram of displacement behavior of $\mathrm{O}^{2-}$ and $\mathrm{Zr}^{4+}$ ions on ferroelastic domain switching.

(a) Stereograph of ion displacement of $\mathrm{O}^{2-}$ and $\mathrm{Zr}^{4+}$ ions on ferroelastic domain switching.

(b) Projective view of picture (a) from $x$-axis direction. Each step in Figs. (a) and (b) on domain switching is corresponded. Arrow in oxygen ions represent the displacement direction of them.

高対称な相へ対称性が増加し，その高対称相の対称性を持 つ状態を通過すると考えられている31),32)。そして，ドメ インウォールの中では一方のドメインに抢歪み方向か ら他方のドメインに抢ける歪み力向へ歪みが連続的に变化 していると考えられている21). ジルコニアのように正方 晶結晶のドメインスイッチングの場合，ドメインウォール の通過により格子が正方晶からより対称性の高い立方晶へ 相転移に逆らうように歪久，立方対称の状態を通過するこ とによって進行する21). 実際に Foitzikらは $\mathrm{t}^{\prime}$ 相の格子像 観察によりドメインウォールは約 $5 \mathrm{~nm}$ の幅を持つ立方晶 的な領域であることを見いたしている33)。つまりドメイ ンウォール中の立方対称の格子はドメインスイッチングの 活性化状態にあり，ドメインウォールの通過は図 60 よ うなイオンの変位に刘応している。

次にこのモデルとドメインスイッチングの活性化エネル ギーの定性的な対応を考える。図6 から分かるように， ジルコニアのドメインスイッチングは酸素イオンの変位に よるところが大きい。図 6 を基にドメインスイッチング に括ける活性化状態に達するまでの酸素イオン変位の大き さを計算すると $0.03 \mathrm{~nm}$ 程度であり，拡散における活性化 状態に達するなでの酸素イオンの移動距離（平均で約 $0.15 \mathrm{~nm}$ ) よりも 1 けた小さい。この $0.15 \mathrm{~nm}$ という值 は，正方晶ジルコニアに存在する 2 種類の酸素イオン間 距離の平均值の半分として見積もったものである。このよ うなわずかなイオン变位は，ドメインスイッチングの際， まず第一に酸素ージルコニウム結合を切断する必要がない こと，そして第二に酸素イオンが最もジルコニウムイオン の接近した位置に近づく必要のないこと，つまり酸素イオ 
ンの周囲のジルコニウムイオンをほとんど押し広げずに済 むことを表している．またすべてのイオンに対してスイッ チング後の行き先が必ず存在しており空孔を作る必要がな い.したがってドメインスイッチングの活性化エネルギー が拡散のそれよりも十分小さいと考えられる。

\section{4. 結 論}

$3 \mathrm{~mol} \% \mathrm{Y}_{2} \mathrm{O}_{3}$ 部分安定化 $\mathrm{ZrO}_{2}$ 結晶を温度, 応力を変え て高温一軸圧縮を行い，以下の結果を得た。

（1）試料を臨界值以上の応力で一軸圧縮すると，正方 晶格子の軸変換（応力方向に $c$ 軸 $\rightarrow a$ 軸）が起こり，正方 晶 $\rightarrow$ 単斜晶転移を伴わないことが確認された。

(2) ドメインスイッチングの発生量の目安として，X 線回折図より (002) (200) ピーク強度比をとることによっ て調べた。その結果， $3 \mathrm{~mol} \% \mathrm{Y}_{2} \mathrm{O}_{3}-\mathrm{ZrO}_{2}$ の強弾性ドメイ ンスイッチングにおいて, 臨界応力以上の一軸圧縮では印 加応力の増加に伴ってドメインスイッチング量が増加した が，その変化は次第に緩慢になった。また本実験の範囲で は, 同一条件の下でスイッチング量は応力印加時間に依存 しないことが確認された.

（3）一軸圧縮によるドメインスイッチングでは，ス イッチングに伴う歪みを緩和するように加圧方向と垂直な 2 方向へスイッチングして，新たなドメイン構造を形成す る. スイッチング量は 2 方向ともに同程度であった.

（4）ドメインスイッチングの開始応力（臨界応力）は 温度の上昇とともに小さくなった。この結果から, 歪み速 度一定の条件の下での $3 \mathrm{~mol} \% \mathrm{Y}_{2} \mathrm{O}_{3}-\mathrm{ZrO}_{2}$ の強弾性ドメイ ンスイッチングの活性化エネルギーは約 $16 \mathrm{~kJ} / \mathrm{mol}$ であっ た。

（5）ドメインスイッチングにおけるイオン変位モデル を提案した。このモデルは, 本実験から得られたドメイン スイッチングの活性化エネルギーの大きさから考えて妥当 なものであった。

\section{文献}

1）堀 三郎,“強勒ジルコニア タフなセラミックス”，内田老 鶴圃 (1990) pp. 2-53.

2) D. Michel, L. Mazerolles, M. Perez and Y. Jorba, J. Mater. Sci., 18, 2618-28 (1983).

3) K. Aizu, J. Phys. Soc. Japan, 27, 387-96 (1969).
4) A. V. Virkar and R. L. K. Matsumoto, J. Am. Ceram. Soc., 69, C224-26 (1986).

5）相津敬一郎，応用物理，38, 825-32 (1969)

6) 相津敬一郎, 日本物理学会誌, 28, 339-51 (1973).

7）石橋善弘, 沢田昭勝, 高木 豊, 日本結晶学会誌, 18, 307-15 (1976).

8）城石芳博，沢田正三，日本物理学会誌，31，128-31（1976）

9）沢田昭勝，鉱物学雑誌， 14, 304-18 (1980).

10) J.-F. Jue and A. V. Virkar, J. Am. Ceram. Soc., 73, 3650-57 (1990).

11) C.-J. Chan, F. F. Lange, M. Rühle, J.-F. Jue and A. V. Virkar, J. Am. Ceram. Soc., 74, 807-13 (1991).

12) K. M. Prettyman, J.-F. Jue and A. V. Virkar, J. Mater. Sci., 27, 4167-74 (1992).

13) G. V. Srinivasan, J.-F. Jue, S.-Y. Kuo and A. V. Virkar, J. Am. Ceram. Soc., 72, 2098-103 (1989).

14) M. G. Cain and M. H. Lewis, Mater. Lett., 9, 309-12 (1990).

15) M. G. Cain, S. M. Bennington, M. H. Lewis and S. Hull, Philosophical Magazine B, 69, 499-507 (1994).

16) A. V. Virkar, J.-F. Jue, P. Smith, K. Mehta and K. Prettyman, Phase Transitions, 35, 27-46 (1991).

17) N. Ishizawa, A. Saiki, N. Mizutani and M. Kato, "Advances in Ceramics, Vol. 24”, Ed. by S. Sōmiya, N. Yamamoto and H. Yanagida, Am. Ceram. Soc., Columbus, Ohio (1988) pp. 479-84.

18）佐伯 淳, 東京工業大学学位論文 (1989).

19）佐伯 淳, 水谷惟恭, J. Ceram. Soc. Japan, 100, 287-91 (1992).

20) K. Mehta and A. V. Virkar, J. Am. Ceram. Soc., 73, 567-74 (1990).

21) E. K. H. Salje, "Phase Transition in Ferroelastic and CoElastic Crystals", Cambridge University Press (1990) pp. 48-49, 90-104.

22) T. S. Shue, T. Y. Tien and I. W. Chen, J. Am. Ceram. Soc., 75, 1108-16 (1992).

23) H. Schubert, J. Am. Ceram. Soc., 69, 270-71 (1986).

24) H. Schubert and G. Petzow, "Advances in Ceramics, Vol. 24", Ed. by S. Sōmiya, N. Yamamoto and H. Yanagida, Am. Ceram. Soc., Columbus, Ohio (1988) pp. 21-28.

25) P. Li and I.-W. Chen, Phys. Rev. B, 48, 10063-73 (1993).

26）若井史博, 阪口修司，加藤英純，宷協， 94, 721-25 (1986).

27）若井史博, 阪口修司, 松野外男, “ジルコニア セラミック 又 6”，内田老鶴围 (1986) pp. 79-89.

28 D. Michel, L. Mazerolles, M. Perez and Y. Jorba, "Advances in Ceramics, Vol. 12”, Ed. by S. Sōmiya, N. Yamamoto and H. Yanagida, Am. Ceram. Soc., Columbus, Ohio (1984) pp. 131-38.

29) K. Aizu., J. Phys. Soc. Japan, 28, 706-16 (1970).

30) J. Weertman and J. R. Weertman, "Elementary Dislocation Theory", Macmillan Company (1964) pp. 167-76.

31) V. K. Wadhawan, Phase Transitions, 3, 3-103 (1982).

32) S. C. Abrahams, Mater. Res. Bull., 6, 881-90 (1971).

33) A. Foitzik, M. Stadtwald-Klenke and M. Rühle, $Z$. Metallkd., 84, 397-404 (1993). 